International Journal of Engineering \& Technology, $7(2.3)(2018) 82-87$
International Journal of Engineering \& Technology
Website: $w w w . s c i e n c e p u b c o . c o m / i n d e x . p h p / I J E T$
Research Paper

\title{
Kampung Pulo Environmental Planning Observed from Biophysical Aspects as Adaptation of Flood in Jakarta
}

\author{
Deffi Ayu Puspito Sari ${ }^{1 *}$, Astrid Sugiana ${ }^{2}$, Ristianti Yuri Ramadhonah ${ }^{1}$, Suci Innaqa ${ }^{1}$, Robbi Rahim ${ }^{3}$ \\ ${ }^{1}$ Environmental Engineering, Universitas Bakrie, Jakarta, Indonesia \\ ${ }^{2}$ Department of Public Policy, Universitas Bakrie, Jakarta, Indonesia \\ ${ }^{3}$ School of Computer and Communication Engineering, Universiti Malaysia Perlis, Kubang Gajah, Malaysia \\ *Corresponding authorE-mail: deffi.sari@bakrie.ac.id
}

\begin{abstract}
Urbanization triggers an increase in urban land conversion. Along with the increasing population and the increasing needs of the shelter, people tend to use the remaining space such as riverbanks and river bodies which are not intended for residential buildings. This has a negative impact on the environmental and river ecosystems, as well as causing the changes in the function of rivers in urban areas, one of it is Ciliwung River which runs through Kampung Pulo. The government seeks to deal with the environmental damage on the riverbank through a revitalization program. This research was conducted to find out the impact of revitalization process by observing biophysical condition of river before and after eviction of people that live in the Ciliwung riverbank and provide a landscape plan of Kampung Pulo segment. Using secondary data of rainfall, land use, land cover and flooded area. The mapping with ArcGIS 10.1 shows there decrease in the area of flood puddle in Kampung Pulo.
\end{abstract}

Keywords: Jakarta flooding, land cover, landscape planning, biophysical aspects, riverbank eviction

\section{Introduction}

Urbanization captures the development and the growth of a city which involves the process of the land conversion to meet the needs of urban communities for the infrastructures and the facilities[1], [2]. The changes in land cover and land use which occur due to the urbanization in the city is a complex interaction of socio-cultural customs that ultimately affect the occurrence of the changes in the environment globally[3]. Revitalization of the region is expected to solve the urban problems, including the increased urban vitality, slum degradation, increased services of facilities and infrastructure networks[4]-[7], and the increased value of the area location.

Along with the growth of the population and the needs of the shelter, people tend to use the remaining space including the riverbanks and river bodies which are used for residence, trade and so forth[8], [9]. High population density can lead to natural disaster such as flood disaster[10]. This also has a negative impact on the river environment such as the disturbed ecosystem balance, and cause the function of the river to change, one of it is Ciliwung which flows through Kampung Pulo. Here, disaster risk reduction is needed to be implemented. It is part of the disaster management cycle[11]. Indonesia with high climate variability such as rainfall [12] can led to extreme condition and natural disasters that became problem to every country in the world[13]-[16]. Floods are frequent natural disasters in Indonesia[17].

Ciliwung River is one of the big river in West java which hails on Mount Parango and flows to the north coast of java through the city of Bogor, Depok and Jakarta. Watershed Area (DAS) consists of the upstream, middle, and downstream, with Ciliwung River Basin Area $\pm 337 \mathrm{~km}^{2}$ which has the interconnectedness and dependence each other[18]. Kelurahan
Jatinegara (Kampung Pulo), Kampung Melayu subdistrict is one of the places that Ciliwung River flows and its condition is currently influenced by the changes in the characteristics of the surrounding environment and also affect the city of Jakarta. Ciliwung River which flows Kampung Pulo is located in Segment 5 . This segment 5 has 15 districts which are flowed by Ciliwung River. In fact, Ciliwung River is no more than functioning as a conduct for solid waste and liquid waste due to the poor spatial layout. Therefore, an integrated planning is needed to manage the sustainable environment in Ciliwung River to create an ecological balance and social aspects. The sustainable environment can be created through the belance and congruence between natural processes and human activities[19].

Kampung Pulo is an area located in east Jakarrta and has the locations around the banks of Ciliwung River. The number of the residents including Kampung Melayu urban village in 2016 is known as 30,666 people. But the number of the residents who live in Kampung Pulo is only 7,007 inhabitants[19].

In the regulation of the Minister of Public Works on Gudelines for Revitalization; of the Regions in 2010, revitalization is defined as an effort to increase the value of land/area through rebuilding in an area that can improve the function of the previous area[19]. Planning and revitalization activities of the area is to increase the activity and the environmental comfort that can impact on improving the quality of community life, growth and stability of local economy.

In order to revitalize the river, one aspects that need to be improved is the biophysical quality of the river environment such as land use, land cover, and flooded areas. This can be achieved through a biophysical aspects approach. Therefore, Ciliwung River environmental planning needs to be done to support the revitalization of the river in Kampung Pulo area. 
The purpose of this study is to analyze part of Ciliwung River revitalization process (focus on Kampung Pulo segment) by observing the biophysical condition of Ciliwung River before and after the eviction and to make landscape plan of Kampong Pulo.

\section{Methods}

This study uses the data sourced from secondary data of the period of 2014-2016 for biophysical data such as rainfall, land use, land cover, and flooded area. The fields survey were conducted by the direct observation/retrieval of data focused on the parameters to be analyzed, documentation and interviews.

The analysis is done by the segment[20], [21], the basis of the segment division is administrative boundary of Kampung Melayu village. Kampung Melayu subdistrict is 8 Rukun Warga (RW). From RW 001, RW 002, RW 003, RW 004, RW 005 RW 006, RW 007, RW 008 are traversed and use Ciliwung River as the administrative boundary. Table 1 shows the boundaries of the segments and the extent of the segment region.

Table 1. The Area of Each Segment

\begin{tabular}{llll}
\hline No & Segment Name & Area (Ha) & Percentage (\%) \\
1 & Segmen RW 001 & 13 & 27,083 \\
2 & Segmen RW 002 & 2,5 & 5,208 \\
3 & Segmen RW 003 & 1,5 & 3,125 \\
4 & Segmen RW 004 & 10 & 20,833 \\
5 & Segmen RW 005 & 5,5 & 11,458 \\
6 & Segmen RW 006 & 7,5 & 15,625 \\
7 & Segmen RW 007 & 3,5 & 7,291 \\
8 & Segmen RW 008 & 4,5 & 9,375 \\
\multicolumn{4}{c}{ Total } \\
\hline \multirow{4}{*}{ Kampung Melayu Subdistrict, 2016 [9]. }
\end{tabular}

Source: Kampung Melayu Subdistrict, 2016 [9].

Biophysical aspect analysis was conducted to determine the condition of river biophysical quality, where all parameters were analyzed descriptively or spatially. The biophysical aspect parameters analyzed included rainfall, land cover, flooded area and land use. In the land closure indicator of this study, the weight of $30 \%$ of the biophysical aspects of the parameter is the Land Clearing Index (IPL) based on the Decree of the Minister of Forestry no. 52 of 2001[22] on the Guidelines for implementing the Water washed management by using the following formula:

$$
\mathrm{IPL}=\frac{L V P}{A R E A} \times 100 \%
$$

IPL $=$ Land Clearing Index

LVP $=$ Area of Permanent Vegetation

The Permanent Vegetation Area (LVP) is a fixed permanent land area whose information can be obtained from the land cover map. Parameter of land use indicator is Land Use Appropriateness (KPL) based on theDecree of the Minister of Forestry no. 52 of 2001[22] on the Guidelines Processing with the formula of calculation as follows:

$$
\mathrm{KPL}=\frac{L P S}{A R E A} \times 100 \%
$$

$\mathrm{KPL}=$ Land Use Compliance

LPS $=$ Area of Use Correct

The spatial analysis [23], [24] was conducted on the land cover parameters (weight $30 \%$ ), vegetation (20\% weight), flooding ( $20 \%$ weight), and the land use (30\% weight). While the other parameters are not analyzed spatially because the criteria obtained generally show the similarity criteria, such as rainfall. Although it is not spatially analyzed, these parameters will be taken into consideration when constructing a block plan.

The analysis will be done by scoring the differences in the level of the condition of biophysical aspect parameters. The use of a very critical score to very good score that is $1-5$. This value represents the criteria of each segment. For example on the land closure parameters, IPL in certain segment value 0 will get a score 1 (very critical) while the land cover with IPL $125 \%$ will get score 2 (critical) and so on. The criteria and parameters used in this study is on Table 2 .

\begin{tabular}{|c|c|c|c|c|c|c|c|}
\hline No & Indicator & Parameter & $\begin{array}{l}\text { Very Critical } \\
\text { Score } 1\end{array}$ & $\begin{array}{l}\text { Critical } \\
\text { Score 2 }\end{array}$ & $\begin{array}{c}\text { Medium } \\
\text { Score } 3\end{array}$ & $\begin{array}{l}\text { Good } \\
\text { Score } 4\end{array}$ & $\begin{array}{l}\text { Very Good } \\
\text { Score } 5\end{array}$ \\
\hline 1. & Climate & Rainfall (mm) & $<500<300$ & $501-1000$ & $1001-2000$ & $2001-2500$ & $>2500$ \\
\hline 2. & $\begin{array}{c}\text { Flood } \\
\text { (Bobot 20\%6) }\end{array}$ & $\begin{array}{c}\text { Flooded Puddle Area ( } \% \\
\text { luas) }\end{array}$ & $>16$ & $11-15$ & $6-10$ & $1-5$ & 0 \\
\hline 3. & $\begin{array}{l}\text { Land Closure } \\
\text { (Bobot 30\%\%) }\end{array}$ & Land Clearing Index (IPL) & 0 & $1-25 \%$ & $26-50 \%$ & $51-75 \%$ & $>75 \%$ \\
\hline 4. & Animals & $\begin{array}{c}\text { Aquatic animals } \\
\text { (number of spacies) }\end{array}$ & 0 & $1-5$ & $6-10$ & $11-15$ & $>16$ \\
\hline \multirow[t]{2}{*}{5.} & $\begin{array}{c}\text { Vegetation (Bobot } \\
\text { 2096) }\end{array}$ & $\begin{array}{l}\text { Mainland Vegetation } \\
\text { (number) }\end{array}$ & 0 & $1-5$ & 6-10 & $11-15$ & $>16$ \\
\hline & & $\begin{array}{c}\text { Continuity of Vegetation } \\
\text { (\%) }\end{array}$ & 0 & $1-25$ & $26-50$ & $51-75$ & $>75$ \\
\hline 6 & $\begin{array}{l}\text { Land Use } \\
\text { (Bobot 30\%) }\end{array}$ & $\begin{array}{l}\text { Lamd Use Adaquary with } \\
\text { RTRW City (KPL) }\end{array}$ & 0.20 & $21-40 \%$ & $41-60 \%$ & $61-80 \%$ & $>80 \%$ \\
\hline
\end{tabular}

Table 2. Criteria and parameter of biophysical aspects

The data and information of the biophysical aspects which have been generated through the scoring will be overlaid. The landscape planning is the stage after the data analysis and synthesis. The stage begins with the preparation of the landscape planning concept for Ciliwung River are based on ecology, then the concept is described in the form of spatial arrangement, circulation, green order, activity and facilities. The concept was developed in the form of a spatial plan, circulation, green plan, activity, and facilities which developed in the form of written and illustrated landscape plan completed with other supporting drawings. The overlay map results will be created using the ArcGIS 10.1 app[25].

\section{Results and Discussion}

Kampung Melayu urban area is about 48 ha and it is divided into 8 Rukun Warga (RW) located along Ciliwung River sides. The geographical conditions, the village of Kampung Melayu declared as one of the village in East Jakarta Administration City. In figure 1 shows Kampung Melayu village map.

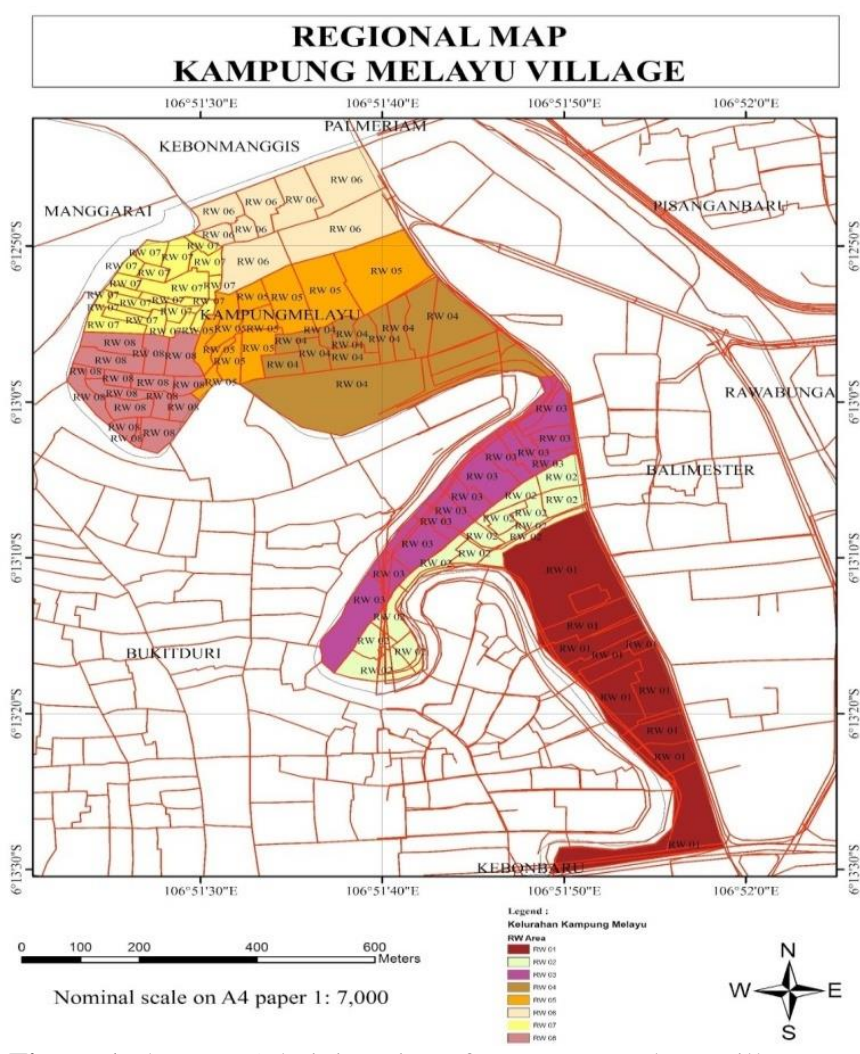

Figure 1. the Map Administration of Kampung Melayu Village 
According to Rais[26], a very complex activity divides into several stages and requires a period which includes the following: 1 . Physical intervention; 2. Economic rehabilitation; 3. Social/ institutional revitalization. But the revitalization stage undertaken by the government of DKI Jakarta in the revitalization of Ciliwung River on the banks of Kampung Pulo Area, only up to the stage of physical intervention. This means that this process includes the improvements, the quality improvements, and physical condition of the buildings, increased the green open space, and open space area.

Climate is a composite of the weather conditions observed over long periods of time and covers a large area. The climate observations in the planning of a landscape are done to create a comfortable atmosphere for the outdoor activities. In this study, the parameters of the studied climate elements are the rainfall.

According to $\mathrm{BMKG}$, in 2016 the annual precipitation in the average planning area reaches between $1,200-1,500 \mathrm{~mm}$. Based on the criteria and parameters of the river landscape planning[22], the rainfall on Ciliwung River footprint is moderate (score 3). This climate condition applies to the all segments given the climatic conditions in each segment.

The pattern of the land use in Ciliwung River environmental planning area is generally still dominated by the densely populated areas. Based on the current largest sequences of the land, the differentiated land use for settlement, offices, public facilities, and green open spaces. The extent and percentage of the land use in each segment can be seen in Table 3.

Table 3. The Types of the Land Use in Kampung Melayu Urban Village in 2016

\begin{tabular}{|c|c|c|c|c|c|c|c|c|c|c|c|}
\hline \multirow{3}{*}{ No } & \multirow{3}{*}{ Segment Name } & \multicolumn{8}{|c|}{ Land Use Types } & \multirow{2}{*}{\multicolumn{2}{|c|}{ Total }} \\
\hline & & \multicolumn{2}{|c|}{ Offices } & \multicolumn{2}{|c|}{$\begin{array}{c}\text { Public } \\
\text { Facilities } \\
\end{array}$} & \multicolumn{2}{|c|}{ Housing } & \multicolumn{2}{|c|}{$\begin{array}{c}\text { Green Open } \\
\text { Space }\end{array}$} & & \\
\hline & & (ha) & $(\%)$ & (ha) & $(\%)$ & (ha) & $(\%)$ & (ha) & $(\%)$ & (ha) & $(\%)$ \\
\hline 1 & Segment RW 001 & 3,64 & 28 & 2,41 & 18,53 & 5,73 & 44,07 & 1,22 & 9,38 & 13 & 27,08 \\
\hline 2 & Segment RW 002 & 0,75 & 30 & 0,0 & 0,0 & 1,75 & 70 & 0,0 & 0,0 & 2,5 & 5,21 \\
\hline 3 & Segment RW 003 & 0,285 & 19 & 0,0 & 0,0 & 1,215 & 81 & 0,0 & 0,0 & 1,5 & 3,13 \\
\hline 4 & Segment RW 004 & 3,07 & 30,7 & 1,13 & 11,3 & 5,38 & 53,8 & 0,42 & 4,2 & 10 & 20,83 \\
\hline 5 & Segment RW 005 & 0,865 & 15,63 & 0,677 & 12,309 & 3,958 & 71,963 & 0,0 & 0,0 & 5,5 & 11,46 \\
\hline 6 & Segment RW 006 & 1,27 & 16,933 & 0,36 & 4,787 & 3,661 & 48,813 & 2,21 & 29,467 & 7,5 & 15,63 \\
\hline 7 & Segment RW 007 & 0,0 & 0,0 & 0,0 & 0,0 & 3,28 & 9,37 & 0,22 & 6,285 & 3,5 & 7,29 \\
\hline 8 & Segment RW 008 & 0,0 & 0,0 & 0,0 & 0,0 & 3,122 & 69,375 & 1,378 & 30,62 & 4,5 & 9,38 \\
\hline & & & & Total & & & & & & 48 & 100 \\
\hline
\end{tabular}

The public facilities which support the residential areas in some places are very less, for example the public toilets, mushola, and others. In additions, the lack of existence of public facilities on the site causes the river as a target for the community to dispose the waste into the river. This causes a decrease in the biophysical quality of the river such as the occurrence of siltation, the quality of river water becomes polluted and the flow of the river water is stopped caused by the accumulation of the waste.

The Regional Regulation no. 2 of 2007 on River Management states that the river samples are used as reforestation of rivers populated by plants to support the ecological, social, cultural, economic and aesthetic benefits and can be utilized for the public facilities such as worship building. This is the basis for conducting the land use analysis on the site. Table 4 shows the extent of the land in each of the appropriate land use segment based on the Local Regulation and the Land Use Value (KPL) score.
Table 4. The Area of Land Use and MPA Results 2016

\begin{tabular}{|c|c|c|c|c|c|c|c|}
\hline \multirow{2}{*}{ No } & \multirow{2}{*}{ Segment Name } & \multirow{2}{*}{$\begin{array}{l}\text { Total } \\
\text { Area } \\
\text { (ha) }\end{array}$} & \multicolumn{2}{|c|}{ Land Use Types } & \multirow{2}{*}{ KPL } & \multirow{2}{*}{ Score } & \multirow{2}{*}{ Information } \\
\hline & & & $\begin{array}{c}\text { Public } \\
\text { Fasilities (ha) }\end{array}$ & $\begin{array}{c}\text { Green Open } \\
\text { Space (ha) }\end{array}$ & & & \\
\hline 1 & Segment RW 001 & 13 & 2,41 & 1,22 & 27,923 & 2 & Critical \\
\hline 2 & Segment RW 002 & 2,5 & 0,0 & 0,0 & 0,00 & 1 & Very Critical \\
\hline 3 & Segment RW 003 & 1,5 & 0,0 & 0,0 & 0,00 & 1 & Very Critical \\
\hline 4 & Segment RW 004 & 10 & 1,13 & 0,42 & 15,500 & 1 & Very Critical \\
\hline 5 & Segment RW 005 & 5,5 & 0,677 & 0,0 & 12,309 & 1 & Very Critical \\
\hline 6 & Segment RW 006 & 7,5 & 0,359 & 2,21 & 34,253 & 2 & Critical \\
\hline 7 & Segment RW 007 & 3,5 & 0,0 & 0,22 & 6,286 & 1 & Very Critical \\
\hline \multirow[t]{2}{*}{8} & Segment RW 008 & 4,5 & 0,0 & 1,378 & 30,622 & 2 & Critical \\
\hline & Jumlah & 48 & & & & & \\
\hline
\end{tabular}

The land use map in 2016 which will be shown in figure 2 that is on segment RW 002, RW 003, RW 004, RW 005, and RW 007 classified as very critical (score 1) in public service and GOS land use. While in segment of RW 001, RW 006 and RW 008 classified as critical (score 2) in the land use of public facility and green open space (GOS).

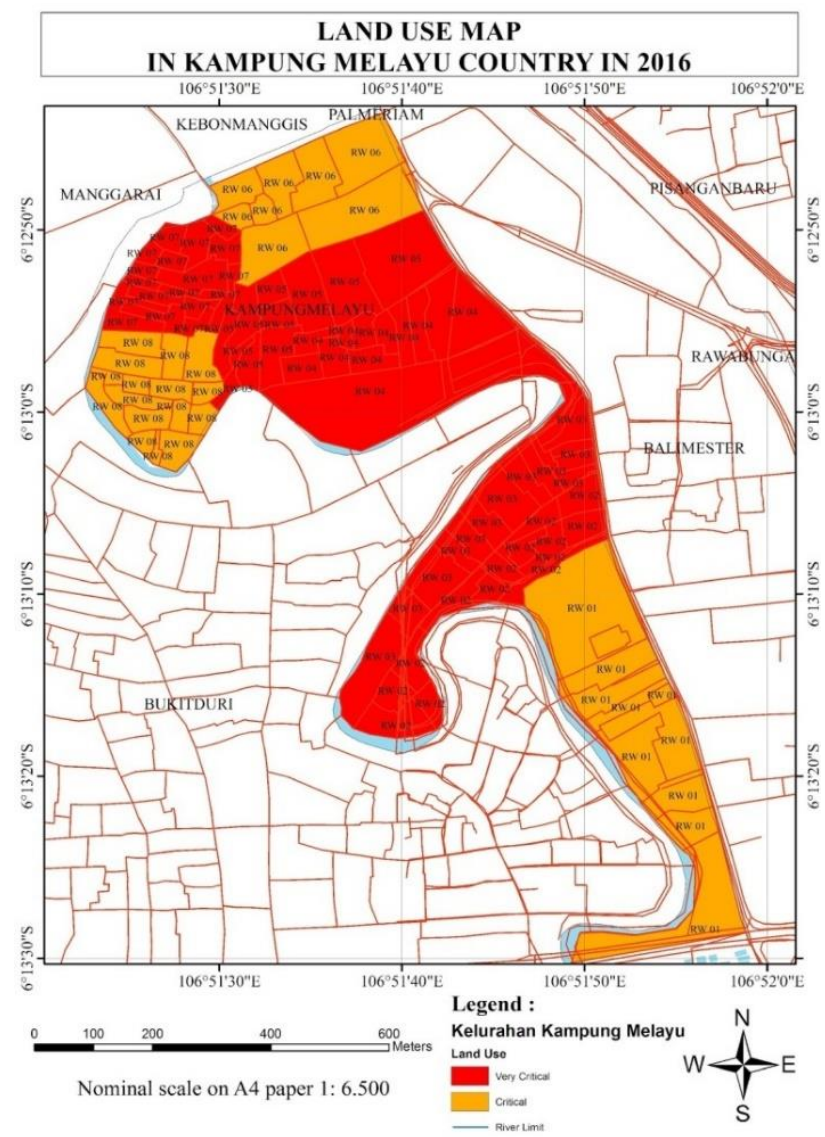

Figure 2. Map of Land Use in Kampung Melayu Urban Village 2016

Generally, in each segment of land cover in the study area, the study is a wake-up area dominated with a very tight density and little open space. The pattern of the land cover settlement dominates on RW 001 segment to RW 08 segment. The cover of land settlement in riverbanks can cause the environmental quality in the river becomes low, and it will impact on the survival of the existing ecosystems. Therefore, the need for relocation of the houses and improving the quality of the environment in the river area.

The open space area is only found in segment RW 001, RW 004 RW 006, RW 007, and RW 008. This open space is such a city park. The existence of the green open space in the form of this city park is a potential which must be developed and preserved. The existence of green open space in the study area is still very less. Therefore, it is necessary to increase the number of the green open space area. 
It will be calculated the extent of vegetated land in each segment from the analysis process of the land cover. This is done to determine the value of land cover index (IPL). Table 5 describes the composition of the vegetated land area in each segment as well as the percentage of the land closure index (IPL).

Table 5. The land Cover for GOS in Kampung Melayu Urban Village in 2016

\begin{tabular}{ccccccc}
\hline No & Segment Name & $\begin{array}{c}\text { Total } \\
\text { Area } \\
(\mathrm{Ha})\end{array}$ & $\begin{array}{c}\text { Area of Land } \\
\text { Vegetation } \\
(\mathrm{Ha})\end{array}$ & IPL (\%) & Score & Information \\
\hline 1 & Segment RW 001 & 13 & 1,22 & 9,38 & 2 & Critical \\
2 & Segment RW 002 & 2,5 & 0,0 & 0,0 & 1 & Very Critical \\
3 & Segment RW 003 & 1,5 & 0,0 & 0,0 & 1 & Very Critical \\
4 & Segment RW 004 & 10 & 0,42 & 4,2 & 2 & Critical \\
5 & Segment RW 005 & 5,5 & 0,0 & 0,0 & 1 & Very Critical \\
6 & Segment RW 006 & 7,5 & 2,21 & 29,4667 & 3 & Medium \\
7 & Segment RW 007 & 3,5 & 0,22 & 6,285 & 2 & Critical \\
8 & Segment RW 008 & 4,5 & 1,378 & 30,622 & 3 & Medium \\
\hline \multicolumn{7}{c}{ Total } \\
\hline
\end{tabular}

Based on Table 5, it can be seen that the highest IPL is $30.622 \%$ contained in Segment RW 008. This indicates that based on the land cover analysis compared with the parameters in quality scaling, the river environmental planning indicators and parameters in this segment are moderate (score 3 ). While the lowest IPL is on segment RW 002, RW 003, and RW 005 classified as very critical (score 1). Figure 3 illustrates the land cover analysis map of the site.

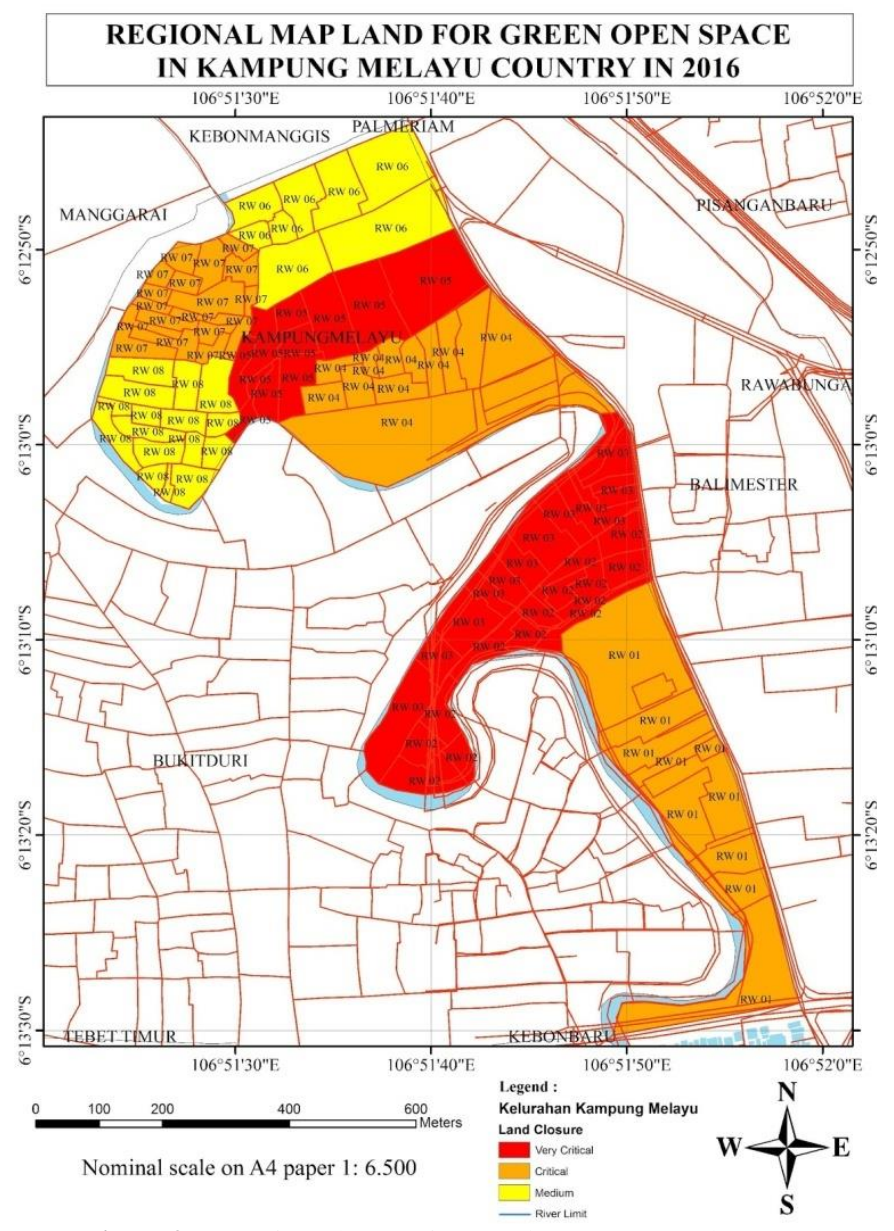

Figure 3. Map of Land Cover for GOS in Kampung Melayu

The flooded areas in some segments occur during the rainy season. Based on the field observations, the interviews with the local communities and the office of Kampung Melayu sub district, there are areas of flood inundation areas in some areas of Kampung Melayu before revitalization or after revitalization as can be seen in table 6 and table 7 .
The map of the flooded area will be presented in figure 4 and figure 5 . This condition is caused by the occurrence of the river degradation caused by garbage, settlements, erosion, and water plants that slow down the river flow and the absence of the drainage channels on the right of the road before it is revitalized. After being revitalized, the flooding area has started to decrease because Ciliwung River in Kampung Pulo area has been widened.

Table 6. The Flood Puddle Area 2014 (before revitalization)

\begin{tabular}{|c|c|c|c|c|c|c|}
\hline $\mathbf{N}_{0}$ & Segment Name & $\begin{array}{l}\text { Area } \\
(\mathrm{Ha})\end{array}$ & $\begin{array}{c}\text { Area of } \\
\text { Flood } \\
\text { Puddle } \\
\text { (Ha) }\end{array}$ & $\begin{array}{l}\text { Percent } \\
(\%)\end{array}$ & Score & Information \\
\hline 1 & Segment RW 001 & 13 & 4,87 & 37,46 & 1 & Very Critical \\
\hline 2 & Segment RW 002 & 2,5 & 2,05 & 82 & 1 & Very Critical \\
\hline 3 & Segment RW 003 & 1,5 & 1,32 & 88 & 1 & Very Critical \\
\hline 4 & Segment RW 004 & 10 & 2,18 & 21,80 & 1 & Very Critical \\
\hline 5 & Segment RW 005 & 5,5 & 1,58 & 28,72 & 1 & Very Critical \\
\hline 6 & Segment RW 006 & 7,5 & 0,87 & 11,60 & 2 & Critical \\
\hline 7 & Segment RW 007 & 3,5 & 0,39 & 11,14 & 2 & Critical \\
\hline \multirow[t]{2}{*}{8} & Segment RW 008 & 4,5 & 0,66 & 14,66 & 2 & Critical \\
\hline & Total & 48 & & & & \\
\hline
\end{tabular}

Table 7. The Flood Puddle Area 2016 (After revitalization)

\begin{tabular}{|c|c|c|c|c|c|c|}
\hline $\mathrm{N}_{0}$ & Segment Name & $\begin{array}{l}\text { Area } \\
\text { (Ha) }\end{array}$ & $\begin{array}{l}\text { Area of } \\
\text { Flood } \\
\text { Puddle } \\
\text { (Ha) }\end{array}$ & $\begin{array}{c}\text { Percent } \\
(\%)\end{array}$ & Score & Information \\
\hline 1 & Segment RW 001 & 13 & 1,42 & 10,92 & 2 & Citical \\
\hline 2 & Segment RW 002 & 2,5 & 0,28 & 11,20 & 2 & Critical \\
\hline 3 & Segment RW 003 & 1,5 & 0,16 & 10,66 & 2 & Critical \\
\hline 4 & Segment RW 004 & 10 & 1,50 & 15 & 2 & Critical \\
\hline 5 & Segment RW 005 & 5,5 & 0,76 & 13,81 & 2 & Critical \\
\hline 6 & Segment RW 006 & 7,5 & 0,41 & 5,47 & 3 & Medium \\
\hline 7 & Segment RW 007 & 3,5 & 0,27 & 7,71 & 3 & Medium \\
\hline \multirow[t]{2}{*}{8} & Segment RW 008 & 4,5 & 0,23 & 5,11 & 3 & Medium \\
\hline & Total & 48 & & & & \\
\hline
\end{tabular}

From the data of the flooded area, the area will be analyzed by comparing it with the planning Parameter[25] (Decree of the Minister of Forestry No. 52 Year 2001 about the Guidelines for Implementing the Water washed management). From the analysis results, will be obtained the Map Analysis Flooded area before revitalization and after revitalization which is shown in figure 4 and figure 5. It is shown in figure 4 in segment RW 001 - RW 005 is very critical (score 1), while segment RW 006 RW 008 is classified as critical (score 2). In figure 5, segment RW $001-$ RW 005 is classified as critical (score 2), while in segment RW 006 - RW 008 is moderate (score 3). 


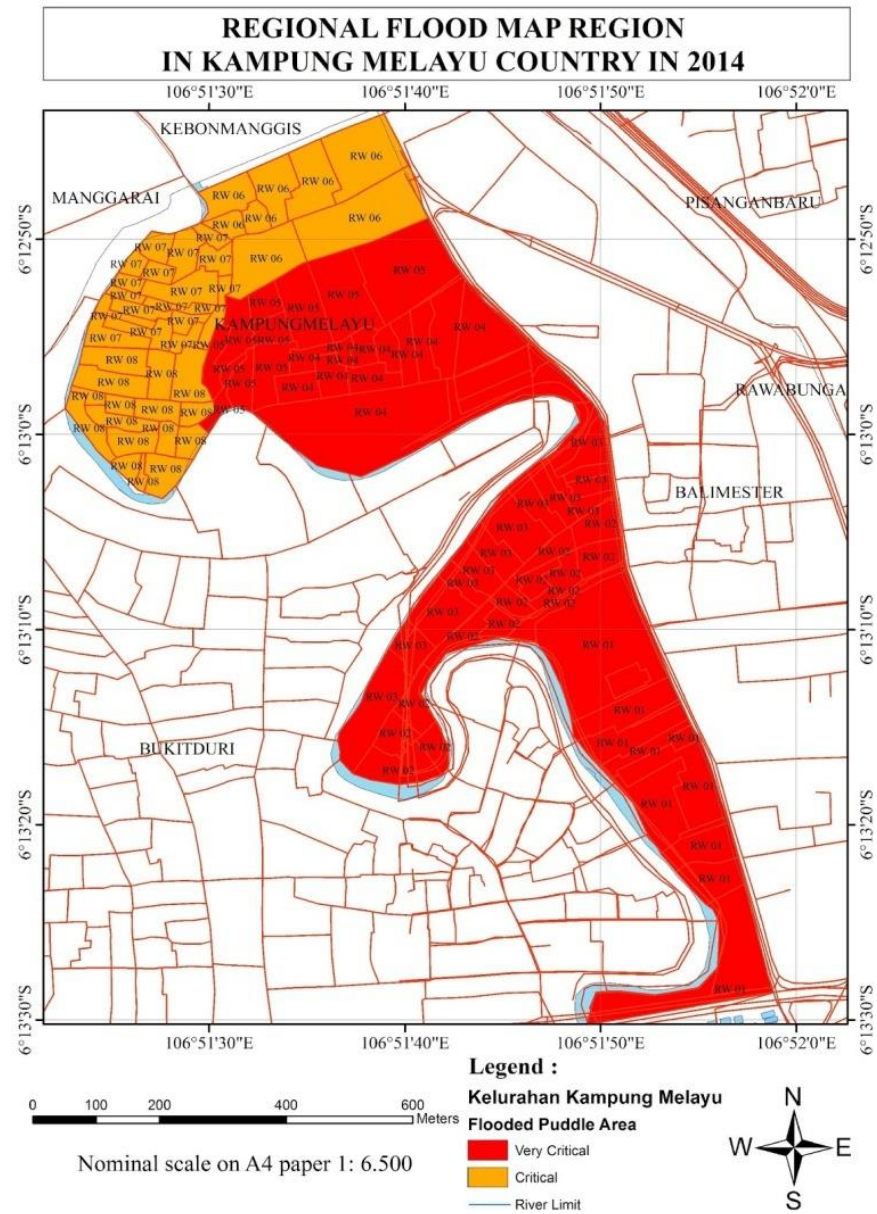

Figure 4. Map of Flood Puddle Area in Kampung Melayu Sub district 2014

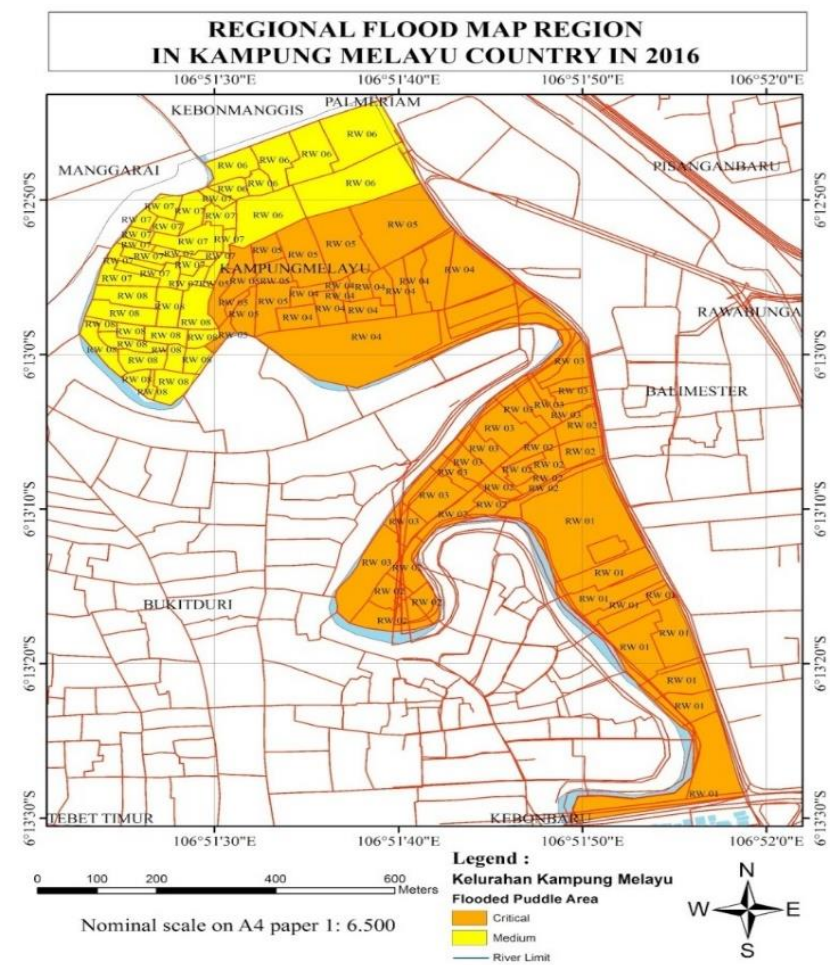

Figure 5. Map of Flood Puddle Area in Kampung Melayu Sub district 2016

The pattern of land use in Ciliwung River environmental planning area is generally still dominated by densely populated areas. Based on the land use table in 2016, the current largest sequence can be differentiated the land use for settlement, offices, public facilities and green open spaces. In Regulation No. 2 of 2007 on
River Management, it is mentioned that the river banks is used as river belt which is filled by the plants to support the ecological, social, cultural, economic and aesthetic benefits and can be utilized for the public facilities. Therefore, this study to be analyzed to take the data for the use of public land and green open space because the use still very lacking in some segments.

In land cover for GOS on segment RW 006 and RW 008 is moderate class because there are wide area for GOS. While on the use of public land and green space in RW 001, RW 006, and RW 008 are critical because in RW 006 and RW 008 segments for public facilities only slightly and are not available.

The land cover for GOS in RW 001 segment, RW 004 and RW 007 are critical since the area of green open space in this segment is only small. While on the use land for public facilities and GOS classified as very critical because in that segment there is only a small area for public facilities and green space.

In land cover for GOS in Segment RW 002, RW 003, and RW 005 are very critical because the area for GOS does not exist at all for the green space area. Thus, on land cover for GOS in RW 002 segment, RW 003, and RW 005 must be available land to establish the area for GOS. While on the land use for public facilities in Segment RW 004 and RW 007 must be available land to establish the area for the public facilities such as MCK. On land use in segment RW 001, RW 006 and RW 008 are included to the critical group in land use for public facilities and GOS. While in the data of 2016, the flood puddle areas at RW 006, RW 007 and RW 008 includes to the middle class because the area is not affected by flooding, the area is in the highlands. In the land use segment in segment RW 002, RW 003, RW 004, RW 005 and RW 007 are very critical since the area for public and green space is small and not even available. While RW 001 , RW 002, RW 003, RW 004 and RW 005 data flooded area in 2016 including the critical area due to the area which are many inhabitants and the area are in the lowlands that cause the flood. The land cover in RW 001, RW 004 and RW 007 segment critical because of the lack of the land to establish the green open space. While in the segment RW 002, RW 003 and RW 005 including to a very critical class because there is no land for GOS. The land in segment is densely populated. In areas of flooding, in segment RW 006, RW 007 and RW 008 are middle class because the area contains GOS land and water catchment area. While in segment RW 001, RW 002, RW 003, RW 004 and RW 005 are critical because there is no green and frequent flooding.

\section{Conclusion}

According to BMKG 2016, the annual rainfall in the area of the average planning reaches between $1,200-1,500 \mathrm{~mm}$, the rainfall on Ciliwung River footprint is moderate (Score 3). Flood inundation area of Kampung Melayu has been decreased before revitalized (2014) and after revitalized (2016). In 2014, RW 001 - RW 005 segment, the area is very critical with a score of 1 $(>16 \%)$. Then in the segment RW $006-\mathrm{RW} 008$ the area is critical with a score of $2(11-15 \%)$. In 2016, in segment RW $001-$ RW 005, the area is critical with score $2(11-15 \%)$, then in the segments RW $006-\mathrm{RW} 008$ the area is including moderate with a score $3(6-10 \%)$.

The types of land use are the public facilities and green open space (GOS). This type of land use is very limited in Kampung Melayu area. From the data obtained, the result of the land use appropriateness (MPA) in RW 002, RW 003, RW 004, RW 005 and RW 007 areas are critical in land use type $1(0-20 \%)$. In RW 001 segment, RW 006, and RW 008 are included in the type of critical land use with a score of $2(21-40 \%)$. The highest IPL is $30.622 \%$ contained in segment RW 008. This indicates that river environmental planning in this segment are moderate (score 3). While the lowest IPL is on segment RW 002, RW 003, RW 005 classified as very critical (Score 1). 
The results of this study can be used as a reference for the government to provide the counseling and socialization to the community that aims for a better environment condition at Ciliwung River. The government must increase the Green Open Space at RW 002, RW 003 and RW 005, and the government replicates the Public Facilities in RW 002, RW 003, RW 007 and RW 008.

\section{Acknowledgment}

This research is funded by The Ministry of Research, Technology and Higher Education, Republic of Indonesia Grant No. 0431/K3/KM/2017 scheme of Overseas Cooperation (Kerjasama Luar Negeri-KLN).

\section{References}

[1] M. G. Hassan, M. D. Akanmu, and A. Y. Bahaudin, "The moderating effect of environmental regulation and policy on the relationship between continuous process improvement and organizational performance: An empirical analysis," Int. J. Eng. Technol., vol. 7, no. 2, pp. 123-126, 2018.

[2] H. Kamaruddin and M. A. Marwan, "Towards extrajurisdictional environmental management in combating transnational environmental crimes in Malaysia from a legal aspect," Int. J. Eng. Technol., vol. 7, no. 2, pp. 26-32, 2018.

[3] C. J. Barrow, "Changes in land use and land cover: A global perspective, edited by W. B. Mayer and B. L. Turner II. Cabridge university press, Cambridge, 1994. ISBN 0521 47085 4, 335 (hardback), xi +573 pp,” L. Degrad. Dev., vol. 6, no. 3, pp. 201-202, Sep. 1995

[4] D. Napitupulu et al., "Analysis of Student Satisfaction Toward Quality of Service Facility," J. Phys. Conf. Ser., vol. 954, no. 1, 2018.

[5] M. Setiawan et al., "E-Business, the impact of regional growth on the improvement of Information and Communication Development," J. Phys. Conf. Ser., vol. 1007, no. 1, p. 012044 Apr. 2018.

[6] J. Suyono, A. Sukoco, M. I. Setiawan, S. Suhermin, and R Rahim, "Impact of GDP Information Technology in Developing of Regional Central Business (Case 50 Airports IT City Development in Indonesia)," in Journal of Physics: Conference Series, 2017, vol. 930, no. 1.

[7] D. Napitupulu, M. Syafrullah, R. Rahim, D. Abdullah, and M. Setiawan, "Analysis of user readiness toward ICT usage at small medium enterprise in south tangerang," J. Phys. Conf. Ser., vol. 1007, no. 1, p. 012042, Apr. 2018

[8] Z. A. Zakaria, J. M. A. Suleiman, and M. Mohamad, "Rainfall frequency analysis using LH-moments approach: A case of Kemaman Station, Malaysia," Int. J. Eng. Technol., vol. 7, no. 2, pp. 107-110, 2018.

[9] N. A. Kamarudin, M. K. A. Kamarudin, R. Umar, A. R. Hassan, F. Lananan, and Sunardi, "Determination of filtration and purification system for flood water filter," Int. J. Eng. Technol., vol. 7, no. 2, pp. 8-12, 2018.

[10] D. A. Puspito Sari, I. Listiyowati, T. Nefianto, and Lasmono, "The Discrepancy between The Programs and Disaster Management Policy in Klapanunggal District, Bogor, West Java," IOP Conf. Ser. Earth Environ. Sci., vol. 135, no. 1, p. 012011, Mar. 2018.

[11] D. A. Puspitosari and R. Afriono, "The Integration of Cultural Resources Management in Disaster Management at Special Region Province of Yogyakarta," Sinergi J. Ilm. Ilmu Manaj., vol. 7, no. 1, Jul. 2017.

[12] Uca, E. Toriman, O. Jaafar, R. Maru, A. Arfan, and A. S. Ahmar, "Daily Suspended Sediment Discharge Prediction Using Multiple Linear Regression and Artificial Neural Network," J. Phys. Conf. Ser., vol. 954, no. 1, 2018.

[13] A. Mursidi and D. A. P. Sari, "Management of Disaster Drought in Indonesia," J. Terap. Manaj. DAN BISNIS, vol. 3, no. 2 , p. 165 , Oct. 2017.

[14] D. Hartama, H. Mawengkang, M. Zarlis, and R. Rahim, "A Research Framework of Disaster Traffic Management to Smart City," in 2017 Second International Conference on Informatics and Computing (ICIC), 2017, pp. 1-5.

[15] V. O. Wati, D. A. P. Sari, and S. Sutisna, "Disaster Relief as Indonesia Soft Power Diplomacy Case of Cyclone Pam in
Vanuatu," Int. J. Multi Discip. Sci., vol. 1, no. 1, pp. 58-69, Feb. 2018.

[16] D. A. P. Sari, M. Malahayati, T. Nefianto, and I. Kertawidana, "Disaster Early Warning and Information Services Meteorology, Climatology and Geophysics Agency's Employees Performance Observed from their Motivation and Competency," Int. J. Multi Discip. Sci., vol. 1, no. 2, pp. 129136, Apr. 2018

[17] N. Mamnunia, D. A. P. Sari, and H. Heridadi, "The Influence of Leadership and Competence in Puskesmas Preparedness for Supporting Flood Disaster Management (Case Study of Samarinda City in East Kalimantan Province, Indonesia)," ADRI Int. J. Environ. Disaster Manag., vol. 1, no. 1, pp. 18-26, Jun. 2017.

[18] M. P. U. dan P. Rakyat, "Peraturan Menteri PUPR No 4/2015 tentang Penetapan Wilayah Sungai," 2015.

[19] M. P. Umum, "Peraturan Menteri Pekerjaan Umum Tentang Pedoman Revitalisasi Kawasan tahun 2010," 2010

[20] A. S. Ahmar et al., "Modeling Data Containing Outliers using ARIMA Additive Outlier (ARIMA-AO)," J. Phys. Conf. Ser., vol. 954, no. 1, 2018.

[21] U. Khair, H. Fahmi, S. Al Hakim, and R. Rahim, "Forecasting Error Calculation with Mean Absolute Deviation and Mean Absolute Percentage Error," J. Phys. Conf. Ser., vol. 930, no. 1 p. 012002, Dec. 2017.

[22] M. Kehutanan, "Peraturan Keputusan Menteri Kehutanan No 52 Tahun 2001 Tentang Pedoman Penyelenggaraan Pengelolaan Daerah Aliran Sungai, Jakarta," 2001.

[23] A. S. Ahmar, Adiatma, and M. K. Aidid, "Crime Modeling using Spatial Regression Approach,” J. Phys. Conf. Ser., vol. 954 , no. 1,2018

[24] D. Priosambodo, "Sebaran Spasial Komunitas Lamun di Pulau Bone Batang Sulawesi Selatan," Sainsmat, vol. 3, no. 2, 2015.

[25] D. A. P. Sari, S. Innaqa, and Safrilah, "Hazard, Vulnerability and Capacity Mapping for Landslides Risk Analysis using Geographic Information System (GIS)," IOP Conf. Ser. Mater. Sci. Eng., vol. 209, no. 1, p. 012106, Jun. 2017.

[26] A. Rais, "Pengaruh Air Payau terhadap Beton yang memakai Semen Padang di Kota Padang Sumatera Barat," 2007. 